\title{
THE DEVELOPMENT OF PIE INITIAL IOTA IN GREEK - REEVALUATION OF EVIDENCE IN CONTEXT OF TYPOLOGICAL DATA (PART 2)
}

Keywords: Greek, laryngeal, phonology, glide, typology

\begin{abstract}
In the following paper selected Greek words with initial $z d$ - or $h$-, which could have developed from Proto-Indo-European initial $\mathrm{H} i \underset{\text { or }}{i-}$-, are analyzed. In the first part the position of the Greek language within the Indo-European family, the Laryngeal Theory and the history of research on the development of initial glide $(H) i$ - in Greek are commented on. In the main segment, divided between the two parts of the paper, the criteria of the selection of the Greek words are put forward and the selected thirteen words analyzed in the light of the development of their initial segments. In the second part, the conclusions made on the basis of the analysis are confronted with theories on scenarios of relative chronology of the sound changes. Finally, typological data is adduced to favour one of the possible scenarios of changes.
\end{abstract}

\section{Analysis}

2.3. The material - forms with initial $z d$ -

\subsection{1. ¿દıaí}

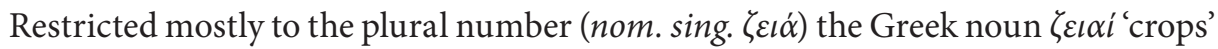
is derived by Beekes from *ieuh ${ }_{1^{-}}$'crop' and compared with Skr. yáva id., Av. yauua-id. and Lith. javai id. The length of the Greek Inlaut vowel, which is incompatible with the comparative material, is explained by metrical lengthening ${ }^{1}$ (Beekes 2010: 497).

1 He also acknowledges a possibility of treating the sequence as a genuine diphthong. The details of the development of the Inlaut, however, are not relevant in this paper. 
Chiara Bozzone proposes a reconstruction of an initial cluster of a laryngeal and iota ${ }^{*} h_{2 / 3} y e u$-id. basing it on the Old Indic compounds Skr. sūyáva- 'having good pastures', ayyavasa- 'having no pastures' (Bozzone 2013: 8). Her choice of the type of reconstructed laryngeals is, however, not supported by any material. The second/ third laryngeal is reconstructed just to preserve the consequence of her theory. Basing on the available material one should therefore reconstruct ${ }^{\star} \mathrm{Hi}$-.

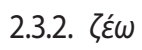

Greek $\zeta \dot{\varepsilon} \omega$ 'to boil' is derived form a PIE root ${ }^{\star} i e s$ - 'to boil, to produce foam'. The Greek form continues ${ }^{*} i e s-o h_{2}$ similarly to Skr. yasati id. and OHG. jesan 'to produce foam, to ferment'. Among others, there is an attested reduplicated Vedic form yayastu 'let it foam' < *ie-ios- (Beekes 2010: 500; LIV: 312). A short vowel in the first syllable suggests an absence of a laryngeal. For the Greek $\zeta \dot{\varepsilon} \omega$ there is, therefore, independent evidence for the reconstruction of sole ${ }^{{ }^{i}}$.

\subsection{3. ไทтท́}

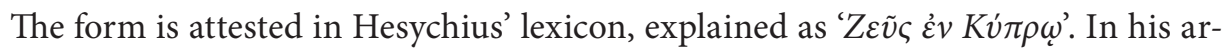
ticle from 1999, García Ramón proved its relation with Vedic yātár 'avenger' (from the root $y \bar{a}-2$ 'to seek, to ask for') and derived both forms from PIE ${ }^{*} i e h_{2}$ ' 'to seek, to find out'. Vedic forms attest an absence of a laryngeal in Anlaut, ìyāná $-<x_{i i-}$

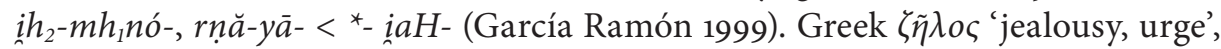

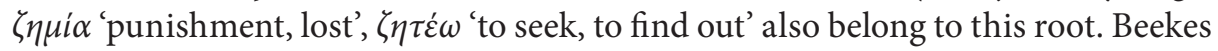
(2010: 501) approves the theory of García Ramón. The gloss then attests the development ${ }^{*} i->z d$ - in Greek.

\subsection{4. ¿uyóv}

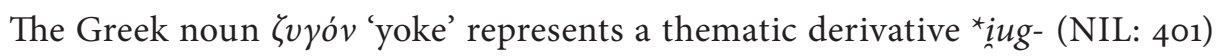
from a PIE root *ieug- 'to yoke'. Other primary Greek derivatives of this root are:

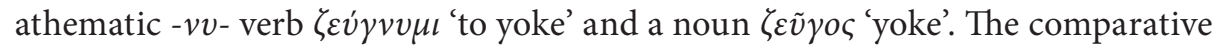
material is abundant, the most important related forms are: Hit. iugan id., Skr. yugám id., Lat. iugum id., Goth. iuk id. (cf. Beekes 2010: 502-503; LIV: 316-317; NIL: $397-400$ ). The compounds cited by $\mathrm{NIL}^{2}$ attest no lengthened vowels which would suggest an initial laryngeal, or its vocalization. Bozzone reconstructs the initial segment as ${ }^{*} h_{2 / 3}$ yewg-id. She supports the laryngeal with Old Indic forms with a long augmented vowel: ấyunak (3 sg. imperf. act.), áyukta (3 sg. mid. aor.). She admits, however, that this is not a strong argument and the length could be secondary (Bozzone 2013: 7). ${ }^{3}$ In the light of this, one should reconstruct just the ${ }_{i}$ i- in the Anlaut.

\footnotetext{
Skr. saṃyujé- 'assembly', Skr. ayujá- 'having no company'.

3 García Ramón (1999: 94) similarly regarded this form as secondary, explaining the length through analogy with other verbs with original ${ }^{\star} H C$ - Anlaut, âyunak to yúnakti 'to bind' and árinak to rinakti 'to set loose' as ávrṇak to varj/vrj 'to turn' $<{ }^{\star} h_{2} u e r g \hat{g}$ - id.
} 


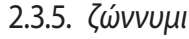

Beekes and Rix ascribe $\zeta \omega v v v \mu \iota$ 'to girdle' to a PIE root *ieh $h_{3}$ id. As it was created on the basis of the aorist stem $\zeta \tilde{\omega} \sigma \alpha l$, the Greek athematic $-v v v$-present stem does not continue a PIE form. The original present stem is most probably attested in the form a Thessalian $\zeta o v \sigma \theta \omega$ from Hesychius ( 3 sg. imperat. med.), which is to be compared with Lith. juos-ti ( $3 \mathrm{sg}$. ind. act.). A formation that is directly inherited from

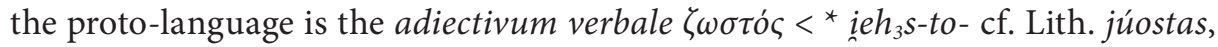
Av. yāsta- (Beekes 2010: 504; LIV: 311). Any evidence for or against a presence of a laryngeal in the Anlaut is lacking, Hence, $\zeta \omega \dot{\omega} v v \mu \iota$ then should not pose an argument in the discussion on the development of ${ }^{*} i$ - in Greek.

\section{Summary}

\subsection{Conclusions from the material analysis}

The analysis of the etymologies, related forms and derivatives of thirteen chosen Greek forms showed that for four of them $(\tilde{\eta} \pi \alpha \rho, \tilde{\eta} \beta \eta, \omega \omega \rho \alpha, \zeta \omega \dot{\omega} v v v \mu l)$ any evidence for or against a presence of an initial laryngeal is lacking. Until some new data or theories about the etymologies of these words show up, the forms themselves are redundant in the discussion about the development of the initial ${ }^{*} i$ - in Greek. The Greek relative pronoun ö $\varsigma$ can be added to the group attesting to the development ${ }^{*} \mathrm{Hi}->h$-, only if one accepts the theory of the $\mathrm{Ce} C$ root structure for PIE. However, since a major proportion of scholars accept that theory, the word will be accepted as a member of this group. There are nine forms then (ten with the pronoun), for which there exists a sufficient amount of comparative material to allow for a secure reconstruction of the Anlaut. The results of the analysis are as follows:

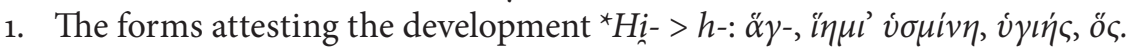

2. The forms attesting the development ${ }^{*} i->z d-: \zeta \dot{\varepsilon} \omega, \zeta \eta \tau \eta \dot{\eta} \rho, \zeta v \gamma o ́ v$.

3. The forms attesting the development ${ }^{\star} H i->z d-: \zeta \varepsilon \iota \alpha i$.

4. Forms with sufficient evidence for neither ${ }^{*} i$ - nor ${ }^{\star} H i-: \tilde{\eta} \pi \alpha \rho, \ddot{\eta} \beta \eta, \ddot{\omega} \rho \alpha, \zeta \dot{\omega} v v v \mu$.

The first and the second group univocally confirms the theory of the development of

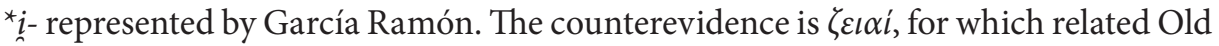
Indic forms suggest a presence of an initial laryngeal in the proto-form. In the light of predominating evidence for the development ${ }^{\star} H i$ - $>h-,{ }^{*} i->z d$ - in Greek, this

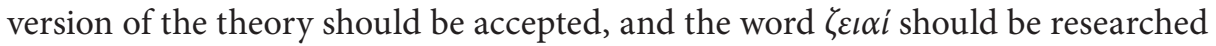
more extensively in the future in search of different explanations for the lengthened vowels in the Sanskrit compounds.

\subsection{Relative chronology}

Basing on the aforementioned assumptions Rau (2010) presented the following relative chronology of the changes: initial PIE ${ }^{*} i$ - during the earliest phase had developed into a phoneme that later turned into Greek $z d$-, then an initial cluster 
${ }^{*} H i$ - was simplified to ${ }^{* i_{2}}{ }^{-4}$ and the new initial glide that arose in that process lenited into $h$ - during the second millennium BC. Bozzone (2013) tried to reformulate Rau's theory: ${ }^{5}$ the initial clusters ${ }^{\star} h_{2}$ - and $h_{3} i$ - developed into Greek $z d$ - as well. According to a theory, presented in 2013 by Andrew Byrd, the second and the third laryngeal, within the scope of the Pinault's law, were to disappear before a palatal element, including ${ }^{*}$. Bozzone supports her theory with the following examples that should

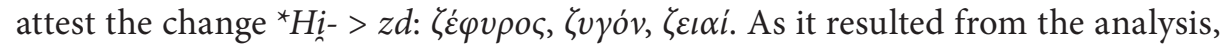
the Greek $\zeta v$ yóv should rather be reconstructed with an initial ${ }^{*} i$-. A genuine example would then include only $\zeta \dot{\varepsilon} \varphi v \rho o \varsigma$ and $\zeta \varepsilon l \alpha i$. The theory is however based on an assumption of a pharyngeal character of the second and third laryngeal (Bozzone 2013: 3), while the phonetic character of the so-called laryngeal phonemes has still not been proved. One should then accept the chronology put forward by Rau.

\subsection{Typological evidence}

Certain typological evidence for universal tendencies in phonetic developments can help to establish the right scenario of changes and favour one of the versions of the theory. An initial segment would be most prone to changes involving some kind of fortition since the articulatory strength is commonly high in the onset of the word. Weakening, on the other hand, most often occurs in the medial and final segments (Hock 1991: 83). That being said, a weakening process may also occur in Anlaut, although not as often.

As it is clear from the typological evidence put forward by Kümmel (2007), a palatal glide [i] which would undergo fortition is most likely to develop into a voiced palato-alveolar affricate $\left[\widehat{\mathrm{d}^{3}}\right]$. This sound is extremely close to the voiced alveolar affricate $\left[\mathrm{d}^{\mathrm{z}}\right]$ which it could very easily further develop into. While it is also possible for a palatal glide to be ultimately reflected as a voiceless glottal fricative $[\mathrm{h}]{ }^{6}{ }^{6}$ it is certainly less common. The evidence then speak in favour of the ${ }^{{ }^{i} i-}>z d$ - development.

Regarding the changes involving the initial segment ${ }^{*} \mathrm{Hi}$-, it is extremely difficult to compare the case with typological data since we are not sure about the exact phonetic value of any laryngeal. Smoczyński (2006: 123) gave an overview of the current relevant theories on that topic. Taking all the theories into account, one can state that the place of articulation for all of the laryngeals most probably was velar or post-velar (involving uvular, pharyngeal, etc.). The majority also agree on the fricative character of the articulation (the opinions differ however about the first laryngeal which, according to some, might have been a stop). It is then safe

4 Rau does not use this orthography. Nonetheless, here this glide is marked with a two in the lower index in order to be differentiated from the original PIE ${ }^{*} i$.

5 Reformulation was allegedly needed due to the lack of expected vocalization of the laryngeal in the sequence ${ }^{\star} \mathrm{H} i$ - which corresponds to HC-.

6 A change of that kind would be seen in the South American dialects of Spanish, where the initial velar fricative $[\mathrm{x}]$, ultimately originating in the Latin initial $i$-, debbucalized into [h]. This process however is not a continuous course of lenition since the first change $i>x$ (from a semivowel to a fricative) represents a case of initial fortition itself. 
to assume that a segment ${ }^{*} H i$ - would constitute a segment consisting of a velar or post-velar fricative sound and a palatal glide. A cluster reduction ${ }^{\star} H i{ }^{*}->^{*} \underline{i}_{2}$ - assumed by Rau is typologically plausible and supported by evidence from Swedish, where an initial Old Swedish $h i$ - simplified into Modern Swedish $i$ - (OSw. hicerta 'heart' > MSw. hjärta id. [jæta], ${ }^{7}$ cf. also hjärna 'brain', hjälpa 'to help').

Following Rau's framework, the last process that needs typological support is the change of the second palatal glide to the Greek glottal fricative. As it was also noted by Bozzone (2013), a change of that kind, according to the Weaking Hierarchy presented by Hock (1991), would actually constitute another case of fortition, since the only way for a glide to lenite would be to disappear completely. However, seeing that a change ${ }^{*} i->h$ - with no intermediate stages is not well attested, it might be the case that we are dealing with a more complex process involving two stages. It has to be noted that the following part is highly speculative, albeit typologically plausible. The palatal glide in question (the second one) might have also fortified but only as far as to a fricative (considering the place of articulation, most probably to a voiced palatal fricative [j]). Then it could have debbucalized into the already attested glottal fricative $[\mathrm{h}]$. Firstly, such a process of initial debbucalization would go well in pair with debbucalization of the initial Greek $s^{-}>h-{ }^{8}$ Secondly, the variation between $\langle y o-/ o-\rangle$, seen in the Mycenaean evidence, might actually represent the process of debbucalization $j->h$ - and not the loss of the glide $i$-. The above considerations, involving Rau's initial assumptions, might be presented in the following way:

1. PIE ${ }^{\star} i$ - fortifies into Pre-Proto-Greek ${ }^{\star} d^{3}$ - (then ultimately develops into Greek $z d$-).

2. PIE ${ }^{\star} H i$ - cluster reduction into Pre-Proto-Greek ${ }^{\star} i_{2}{ }^{-}$.

3. Pre-Proto-Greek ${ }^{*} i_{2}$ - fortifies into Proto-Greek ${ }^{*} j$-.

4. Proto-Greek ${ }^{\star} j$ - debbucalises into Mycenaean Greek $h$ - (with the Linear B orthographic variation as an attestation of the on-going process).

Such a scenario, although speculative, rewrites the whole process in a way that is compatible with typological tendencies, the Weakening Hierarchy and attested Mycenaean orthographic variation.

\section{References}

Beekes R.S.P. 2010. Etymological dictionary of Greek. Leiden.

Bozzone Ch. 2013. Initial "Yod” in Greek and the etymology of Gk. i $\pi \pi$ o ৎ 'horse'. - Jamison S.W., Melchert C.H., Vine B. (eds.). Proceedings of the $24^{\text {th }}$ annual UCLA Indo-European conference. Bremen: 1-26.

Byrd A. 2015. The Indo-European syllable. Leiden, Boston.

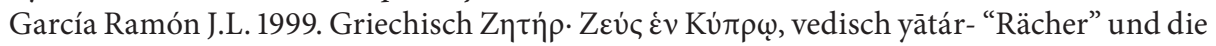
Vertretung von ^i- im Griechischen. - Eichner H., Luschützky H.Ch., Sadovski V. (eds.). Compositiones Indogermanicae in memoriam Jochem Schindler. Praha: 77-96.

From Proto-Germanic *hert-, cf. Goth. haírto, OHG. herza, OE. heorte (Hellquist 1922: 240).

8 It is furthermore possible that both these changes were a part of a general tendency of debbucalization during a certain phase of Greek. 
Hellquist E. 1922. Svensk etymologisk ordbok. Lund.

Hock H.H. 1991. Principles of historical linguistics. Berlin.

Kümmel M. 2007. Konsonantenwandel. Bausteine einer Typologie des Lautwandels und ihre Konsequenzen für die vergleichende Rekonstruktion. Wiesbaden.

LIV = Rix H. 2001. Lexikon der indogermanischen Verben. Wiesbaden.

$\mathrm{NIL}=$ Wodtko D.S., Irslinger B., Schneider C. 2008. Nomina im indogermanischen Lexikon. Heildeberg.

Rau J. 2010. Greek and Proto-Indo-European. - Bakker E.J. (ed.). A companion to the Ancient Greek language. Malden: 171-188.

Smoczyński W. 2006. Rzut oka na teorię laryngalnych. - Krasnowolska A., Maciuszak K., Mękarska B. (eds.). In the Orient where the gracious light... Satura Orientalis in honorem Andrzej Pisowicz. Kraków: 119-165. 